\title{
Plasma levels of progesterone, Provera, oestradiol-17 $\beta$, and 13,14-dihydro-15-keto-prostaglandin $F$ in cows treated with Provera-impregnated intravaginal sponges
}

\author{
J. F. Smith, R. J. Fairclough and A. J. Peterson \\ Ministry of Agriculture and Fisheries, Research Division, Ruakura Animal Research Station, \\ Hamilton, New Zealand
}

\begin{abstract}
Summary. Plasma concentrations of progesterone and Provera were measured daily in 3 cows during 21 days of treatment with Provera-impregnated intravaginal sponges. Plasma concentrations of oestradiol-17 $\beta$ and 13,14-dihydro-15-keto-prostaglandin F (PGFM) were measured hourly from $5 \mathrm{~h}$ before until $62 \mathrm{~h}$ after sponge removal. The profile of progesterone concentrations indicated that luteolysis occurred at the expected time (Days 19 to 23 of the cycle), even though plasma Provera concentrations were $150-250 \mathrm{pg} / \mathrm{ml}$. The occurrence of peaks of PGFM after sponge withdrawal suggests that PGF- $2 \alpha$ release is stimulated by falling levels of progestagen.
\end{abstract}

\section{Introduction}

An increase in prostaglandin (PG) F concentrations is coincident with the fall in levels of plasma progesterone at luteolysis in the cow (Peterson, Fairclough, Payne \& Smith, 1975a; Kindahl, Edqvist, Bane \& Granström, 1976). When cows are treated with intravaginal progestagenimpregnated sponges for 21 days oestrus and ovulation are effectively synchronized within 3 days (Smith, 1974). In similarly treated sheep the corpora lutea regress at the normal time (Smith \& Robinson, 1969), but oestrus and ovulation are blocked by the exogenous progestagen during the later stages of treatment. The progestagen used in the sponges is often the synthetic compound 6a-methyl-17 $\alpha$-acetoxy-progesterone (Provera: Upjohn) but no data appear to be available on the plasma levels of Provera during treatment in either sheep or cattle.

We have therefore studied the plasma concentrations of progesterone and Provera in cows bearing Provera-impregnated intravaginal sponges and the effect of sponge withdrawal on the plasma levels of oestradiol-17 $\beta$ and the 13,14-dihydro-15-keto metabolite of PGF-2 $\alpha$ (PGFM) to determine if a decline in progestagen stimulates the release of PGF.

\section{Materials and Methods}

\section{Treatments}

Three (3) multiparous non-lactating Friesian cows with regular 19-22-day oestrous cycles were used. Sheep sponges, each $35 \mathrm{~mm}$ in diameter, were impregnated with $50 \mathrm{mg}$ Provera and a bunch of 10 were used for each cow to give a total dose of $500 \mathrm{mg}$ (Smith, 1974). The sponges were inserted during the luteal phase of the cycle, Day 14 in Cow 599, Day 9 in Cow 601 and on Day 10 in Cow 604, and were removed 21 days later. The cows were run together with a vasectomized bull and the onset of oestrus (Day 0 ) was designated as being the time the cow was first observed to stand when mounted by the bull. The cows were inspected for oestrous activity at hourly intervals after sponge withdrawal.

Blood $(20 \mathrm{ml})$ was withdrawn from indwelling jugular cannulas into pre-cooled syringes. Daily samples were collected at 09:00 h while the sponges were present in the vagina; samples 
were then taken every hour from $5 \mathrm{~h}$ before and until $62 \mathrm{~h}$ after sponge removal. The blood was centrifuged within 10 min of sampling and the plasma stored at $-20^{\circ} \mathrm{C}$.

\section{Hormone assays}

Oestradiol-17 $\beta$. Oestradiol-17 $\beta$ concentrations were determined by radioimmunoassay (Peterson, Fairclough \& Smith, 1975b). An ethereal extract of $2 \mathrm{ml}$ plasma was chromatographed on Sephadex LH-20 micro-columns. The antiserum used was raised in sheep against oestradiol-17 $\beta-6$-bovine serum albumin and only oestrone (3.9\%) and oestradiol-17 $\alpha$ $(0.82 \%)$ showed any significant cross-reactivity. A recovery rate of $70-80 \%$ was obtained over a range of oestradiol- $17 \beta$ levels $(10-50 \mathrm{pg})$. The within-assay coefficient of variation was 10 $15 \%$. The between-assay coefficient of variation, calculated from control samples run with each assay, was $16 \%$. The least amount distinguishable from zero was $5 \mathrm{pg}$. All samples were assayed in duplicate.

$P G F M$. The plasma concentrations of PGFM were measured by radioimmunoassay (Fairclough \& Payne, 1975). Plasma $(0.5-1.0 \mathrm{ml})$ was acidified to $\mathrm{pH} 3$ with $1 \mathrm{~N}-\mathrm{HCl}$ and extracted with 4 volumes ether. Assays were conducted in duplicate using an antiserum raised against a PGFM-BSA conjugate. This antiserum had a $20 \%$ cross-reaction with 15 -keto-PGF$2 \alpha$ and $<1 \%$ cross-reaction with all other prostaglandins tested. The antiserum did not distinguish between 13,14-dihydro-15-keto-PGF-1 $\alpha$ and 13,14-dihydro-15-keto-PGF-2 $\alpha$ and results are expressed as PGFM equivalents. The sensitivity of the assay was $0.15 \mathrm{ng} / \mathrm{ml}$ plasma and the interassay coefficient of variation was $14.4 \%(n=8)$.

Progesterone. Progesterone levels were determined by radioimmunoassay using an antiserum raised in sheep against a progesterone-11-BSA conjugate (Fairclough, Hunter \& Welch, 1975). This antiserum had a $4.2 \%$ cross-reaction with $20 \beta$-hydroxy-progesterone and $<1 \%$ with all other steroids tested. The interassay coefficient of variation was $15 \cdot 5 \%(n=26)$ and the sensitivity of the assay was $0.15 \mathrm{ng} / \mathrm{ml}$ plasma.

Provera. The plasma Provera concentrations were determined by radioimmunoassay using an antiserum raised in goats against a Provera-3-bovine serum albumin complex. This antiserum, which was supplied by Dr K. T. Kirton, Upjohn, showed little cross-reactivity with endogenous steroids, including progesterone (Cornette, Kirton \& Duncan, 1971). Plasma samples $(1.0 \mathrm{ml})$ were extracted with 4 volumes petroleum ether and the extract was evaporated to dryness under $\mathrm{N}_{2}$, and then transferred to Lipidex columns $(8 \times 0.4 \mathrm{~cm})$ with $2 \times 100 \mu \mathrm{l}$ hexane and eluted with the same solvent. The Provera containing fraction (7.2-9.6 ml) was evaporated to dryness under $\mathrm{N}_{2}$. This procedure separates Provera from most other plasma steroids except progesterone which is eluted in the $5.5-8.0 \mathrm{ml}$ fraction (Fairclough, Rabjohns \& Peterson, 1977); but since the cross-reactivity of the antiserum with progesterone was negligible $(<0.1 \%)$, the assay was considered specific for Provera. Each sample was extracted and assayed in duplicate against Provera standards $(0.0-2.0 \mathrm{ng})$ by a radioimmunoassay technique similar to that used for progesterone. All results were corrected for procedural losses. The mean recovery of labelled Provera from plasma was $65 \pm 6 \cdot 5 \%$. The accuracy of the method, assessed as the recovery of $500 \mathrm{pg}$ Provera from plasma, was $107 \pm 10 \cdot 3 \%(n=18)$. The interassay coefficient of variation for samples ranging in concentrations between 115 and $607 \mathrm{pg} / \mathrm{ml}$ was $9.7 \%(n=$ 18). The least amount distinguishable from zero was $65 \mathrm{pg} / \mathrm{ml}$. The isotope used was $\left[1,2-{ }^{3} \mathrm{H}\right]$ $6 \alpha$-methyl-17 $\alpha$-hydroxy-progesterone acetate (sp. act. $40-60 \mathrm{Ci} / \mathrm{mmol}$ : New England Nuclear).

\section{Results}

The cows did not exhibit oestrus during Provera treatment and the removal of the sponges led to a precise synchronization of the onset of oestrus: oestrus occurred 37,43 and $35 \mathrm{~h}$ after sponge removal for Cows 599, 601 and 604 respectively. 
Progesterone. The concentration of progesterone in the 3 cows rose from $3-10 \mathrm{ng} / \mathrm{ml}$ at time of sponge insertion to $5-17 \mathrm{ng} / \mathrm{ml} 6$ days later and then declined to levels of $1-2 \mathrm{ng} / \mathrm{ml}$ by the 9th day. These low levels were maintained for the remainder of treatment (Text-fig. 1).

Provera. The concentrations of Provera increased rapidly following sponge insertion but there was considerable variability amongst cows in the maximum levels recorded. At 5-7 days after insertion the plasma concentrations had fallen to a plateau of $150-250 \mathrm{pg} / \mathrm{ml}$ and they remained at this level until sponge removal. Concentrations fell rapidly once the sponges were removed and were undetectable within 12-24 h (Text-fig. 1).

$P G F M$. Although there was variation between the individual cows in the number and magnitude of PGFM peaks, all cows showed at least one marked peak within $18 \mathrm{~h}$ of sponge removal. The maximum concentrations recorded were between 300 and $500 \mathrm{pg} / \mathrm{ml}$ (Text-fig. 2).

Oestradiol-17 $\beta$. All 3 cows showed variable numbers of peaks of oestradiol-17 $\beta$ before the onset of oestrus. Levels ranged from basal concentrations of $10 \mathrm{pg} / \mathrm{ml}$ to peak values of $80-100$
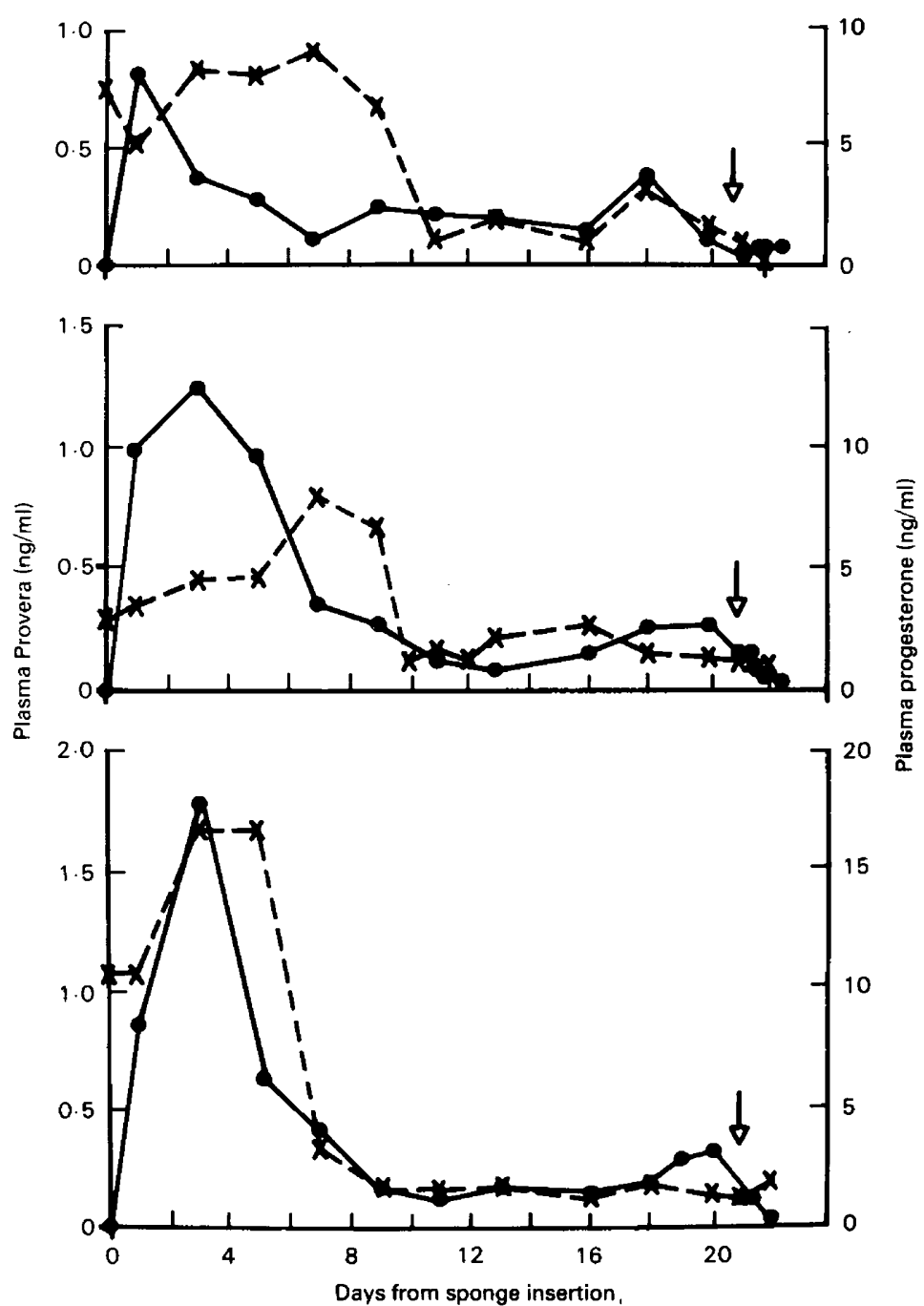

Text-fig. 1. Jugular plasma concentrations of Provera (- - - ) and progesterone $(x---x)$ in the 3 cows treated for 21 days with Provera-impregnated intravaginal sponges. The arrow indicates the day of sponge removal. 

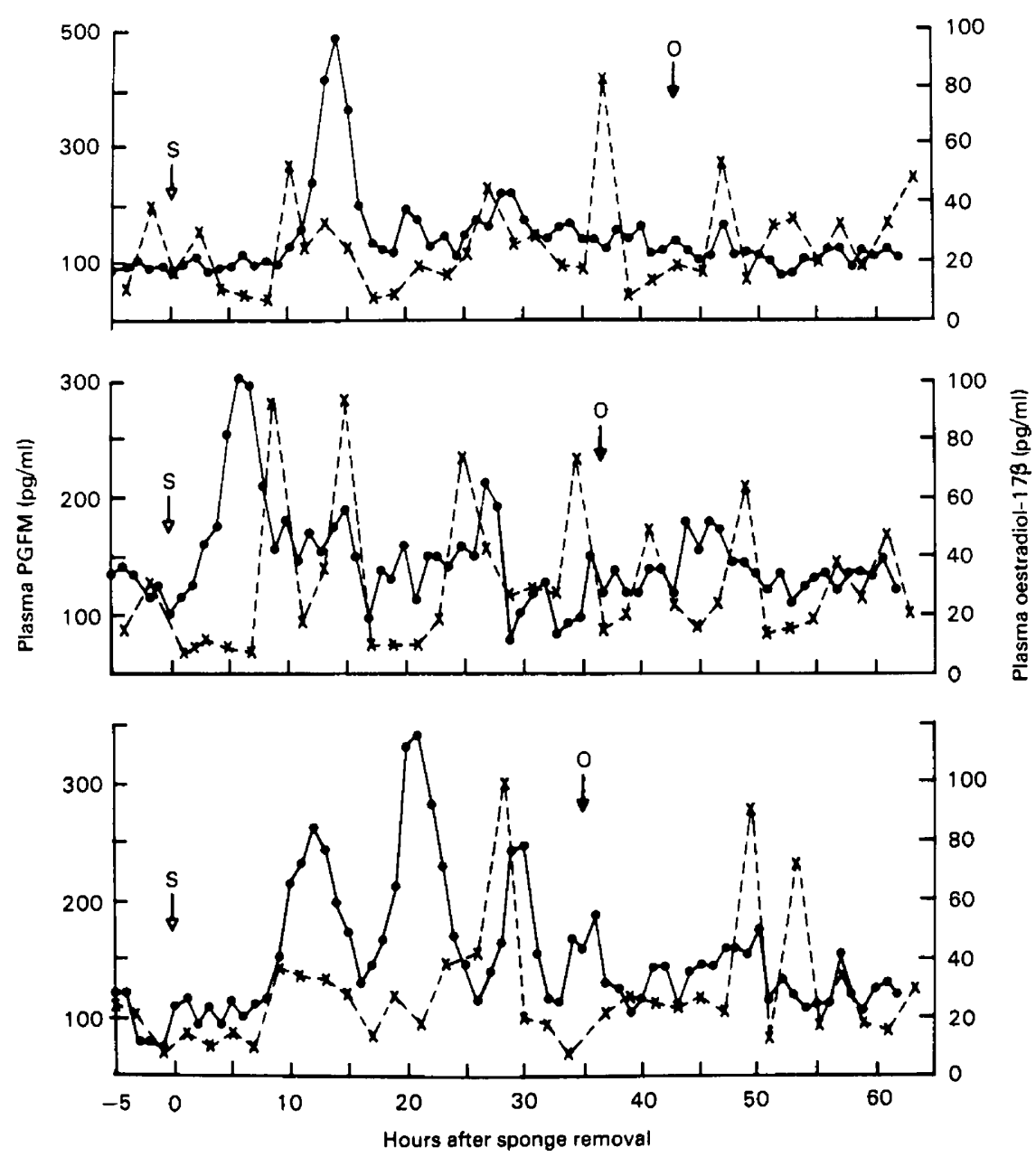

Text-fig. 2. Jugular plasma concentrations of PGFM (- $\longrightarrow)$ and oestradiol-17 $(x---x)$ following sponge removal (S). $\mathrm{O}=$ oestrus.

$\mathrm{pg} / \mathrm{ml}$. The onset of oestrus occurred 2-6 h after an oestrogen peak. There was no obvious temporal relationship between either the onset of oestrus and peaks of PGFM or between peaks of oestradiol-17 $\beta$ and peaks of PGFM.

\section{Discussion}

The estimated progestational activity of Provera is $20-50$ times higher than that of progesterone (Shelton \& Robinson, 1967), and it has a 30 times higher receptor affinity (Terenius, 1974). Assuming that a similar relationship pertains to the cow then the concentrations of 150-250 $\mathrm{pg} / \mathrm{ml}$ seen in the later stages of treatment should correspond in activity to progesterone concentrations of 3-12 $\mathrm{ng} / \mathrm{ml}$ and such levels are found during the luteal phase of the cycle (Peterson et al., 1975a). The plasma profile of Provera observed during treatment could explain the higher fertility after a 10-day progestagen treatment in cows (Sreenan, 1975). The initially high levels of Provera could be important because a direct relationship between progestagen concentration and fertility has been shown in sheep (Robinson, 1970) and cows (Corah, Quealy, Dunn \& Kaltenbach, 1974). 
The levels of oestradiol- $17 \beta$ recorded following sponge removal were higher than those found for untreated cows around oestrus (Peterson et al., 1975a). This finding concurs with that of Hansel et al. (1975). Similarly elevated levels of oestrogen after progestagen treatment have been reported for sheep (Smith \& Robinson, 1970). These elevated levels may in part explain the lowered fertility encountered following the use of this long-term (16-21 days) treatment for control of oestrus in sheep and cattle. The elevated oestrogen levels could affect the pattern of production of cervical mucus (Smith \& Allison, 1971), sperm transport (Quinlivan \& Robinson, 1969) and ovum transport and cleavage rate (Wishart \& Young, 1974).

In the present study the corpus luteum regressed at the expected time (Days 19 to 23 of the cycle) even though Provera concentrations in the peripheral plasma were $150-250 \mathrm{pg} / \mathrm{ml}$. Similar findings have been reported in sheep (Ginther, 1968; Smith \& Robinson, 1969) and cows (Hill, Lamond, Henricks, Dickey \& Niswender, 1971). Furthermore, the timing of luteolysis does not appear to be affected when cows are treated with intravaginal sponges impregnated with progesterone (J. F. Smith, unpublished observations). It seems therefore that falling levels of progesterone in the peripheral circulation are not an absolute requirement for the demise of the corpus luteum in sheep and cattle.

The fact that in this study PGFM concentrations increased after the removal of the progestagen-impregnated sponges raises the possibility that the surges in plasma PGFM concentrations observed in cows around Days 18-19 of the normal oestrous cycle may have been due to the withdrawal of progesterone (Peterson et al., 1975a; Kindahl et al., 1976). It has been reported that the concentration of PGF- $2 \alpha$ in utero-ovarian plasma of sheep increases after treatment with Estrumate, a synthetic prostaglandin, during the mid-luteal phase of the cycle (Challis, Forster, Furr, Robinson \& Thorburn, 1976).

We propose on the basis of our findings that the surges in plasma PGF concentrations reported in normal cows during the time of falling plasma progesterone concentrations (Nancarrow et al., 1973) may be necessary to ensure the rapid and complete regression of the corpus luteum. A similar proposal has been advanced for sheep (Thorburn, Cox, Currie, Restall \& Schneider, 1973).

We thank $\mathrm{Mr} \mathrm{H}$. Drost and the staff of the Fertility Section, Ruakura, for help in the management and blood sampling of the cows, and Margaret Rabjohns, Pamela Lane and Patricia Woolford for excellent laboratory assistance. The PGFM and Provera antisera were kindly provided by Dr K. T. Kirton, Upjohn Co, Kalamazoo, U.S.A.

\section{References}

Challis, J.R.G., Forster, C.S., Furr, B.J.A., Robinson, J.S. \& Thorburn, G.D. (1976) Production of prostaglandin $F_{\alpha}$ in ewes following luteal regression induced with a prostaglandin analogue, Estrumate (Cloprostenol; ICI 80996). Prostaglandins 11, 537543.

Corah, L.R., Quealy, A.P., Dunn, T.G. \& Kaltenbach, C.C. (1974) Prepartum and postpartum levels of progesterone and estradiol in beef heifers fed two levels of energy. J. Anim. Sci. 39, 380-385.

Cornette, J.C., Kirton, K.T. \& Duncan, G.W. (1971) Measurement of medroxyprogesterone acetate (Provera) by radioimmunoassay. J. clin. Endocr. Metab. 33, 459-466.

Fairclough, R.J. \& Payne, E. (1975) Radioimmunoassay of 13,14-dihydro-15-keto-prostaglandin $F$ in bovine peripheral plasma. Prostaglandins 10, 266272.
Fairclough, R.J., Hunter, J.T. \&elch, R.A.S. (1975) Peripheral plasma progesterone and utero-ovarian prostaglandin $F$ concentrations in the cow around parturition. Prostaglandins 9, 901-914.

Fairclough, R.J., Rabjohns, M.A. \& Peterson, A.J. (1977) Chromatographic separation of androgens, estrogens and progestogens on hydroxyalkoxypropyl-Sephadex (Lipidex ${ }^{\mathrm{R}}$ ). J. Chromat. 133, 412414.

Ginther, O.J. (1968) Influence of exogenous progesterone and the uterus on ovarian activity in sheep. Endocrinology 83, 613-615.

Hansel, W., Schechter, R.J., Malven, P.V., Simmons, K.R., Black, D.L., Hackett, A.J. \& Saatman, R.R. (1975) Plasma hormone levels in 6-methyl-17acetoxyprogesterone and estradiol benzoate treated heifers. J. Anim. Sci, 40, 671-681. 
Hill, J.R., Jr, Lamond, D.R., Henricks, D.M., Dickey, J.F. \& Niswender, G.D. (1971) The effect of Melengestrolacetate (MGA) on ovarian function and fertilization in beef heifers. Biol. Reprod. 4, 16-22.

Kindahl, H., Edqvist, L.E., Bane, A. \& Granström, E. (1976) Blood levels of progesterone and 15-keto13,14-dihydroprostaglandin $F_{2 \alpha}$ during the normal oestrous cycle and early pregnancy in heifers. Acta endocr., Copenh. 82, 134-149.

Nancarrow, C.D., Buckmaster, J., Chamley, W., Cox, R.I., Cumming, I.A., Cummins, L., Drinan, J.P., Findlay, J.K., Goding, J.R., Restall, B.J., Schneider, W. \& Thorburn, G.D. (1973) Hormone changes around oestrus in the cow. J. Reprod. Fert. 32, 320321, Abstr.

Peterson, A.J., Fairclough, R.J., Payne, E. \& Smith, J.F. (1975a) Hormonal changes around bovine luteolysis. Prostaglandins 10, 675-684.

Peterson, A.J., Fairclough, R.J., \& Smith, J.F. (1975b) Radioimmunoassay of estradiol- $17 \beta$ in bovine peripheral plasma with and without chromatography. Steroids 25, 487-496.

Quinlivan, T.D. \& Robinson, T.J. (1969) Numbers of spermatozoa in the genital tract after artificial insemination of progestagen-treated ewes. $J$. Reprod. Fert. 19, 73-86.

Robinson, T.J. (1970) Fertility following synchronization of oestrus in the sheep with intravaginal sponges. II. Effect of dose of progestagen and rate of absorption. Aust.J. agric. Res. 21, 783-792.

Shelton, J.N. \& Robinson, T.J. (1967) The evaluation of several progestagen treatments in the entire cyclic ewe. In The Control of the Ovarian Cycle in the Sheep, pp. 39-47. Ed. T. J. Robinson. Sydney University Press.

Smith, J.F. (1974) Synchronisation of oestrus in cattle. N.Z. J. Agric. 129, 26-31.

Smith, J.F. \& Allison, A.J. (1971) The effect of exogenous progestagen on the production of cervical mucus in the ewe. J. Reprod. Fert. 24, 279-282.

Smith, J.F. \& Robinson, T.J. (1969) Luteal function in the Merino ewe and the effect of exogenous progestagen. J. Endocr. 44, 79-89.

Smith, J.F. \& Robinson, T.J. (1970) The effect of exogenous progestagen on the levels of free oestrogen in the ovarian vein plasma in the ewe. $J$. Endocr. 48, 485-496.

Sreenan, J.M. (1975) Effect of long- and short-term intravaginal progestagen treatments on synchronization of oestrus and fertility in heifers. J. Reprod. Fert. 45, 479-485.

Terenius, L. (1974) Affinities of progestogen and estrogen receptors in rabbit uterus for synthetic progestogens. Steroids 23, 909-919.

Thorburn, G.D., Cox, R.I., Currie, W.B., Restall, B.J. \& Schneider, W. (1973) Prostaglandin F and progesterone concentrations in the utero-ovarian venous plasma of the ewe during the oestrous cycle and early pregnancy. J. Reprod. Fert., Suppl. 18, 151-158.

Wishart, D.F. \& Young, I.M. (1974) Artificial insemination of progestin (SC 21009)-treated cattle at predetermined times. Vet. Rec. 95, 503-508.

Received 13 June 1978 